\title{
Rola daratumumabu w leczeniu chorych na nawrotowego i opornego szpiczaka plazmocytowego
}

\author{
The role of daratumumab in the treatment of patients \\ with relapsed/refractory plasma cell myeloma
}

\author{
Aleksander Salomon-Perzyński, Krzysztof Jamroziak \\ Klinika Hematologii, Instytut Hematologii i Transfuzjologii, Warszawa
}

\begin{abstract}
Streszczenie
Mimo znaczqcego postępu terapeutycznego w ostatnich dwóch dekadach szpiczak plazmocytowy (PCM) pozostaje choroba nawrotowa i nieuleczalna. Gtówne wyzwanie w praktyce klinicznej stanowi leczenie chorych na PCM z grupy tak zwanego wysokiego ryzyka. W wielu badaniach klinicznych wykazano, że $w$ dobie nowych leków przeciwszpiczakowych, $w$ tym inhibitorów proteasomu (PI) oraz leków immunomodulujacych (IMiD), obecność aberracji cytogenetycznych wysokiego ryzyka, a wiec del17p, t(4;14), t(14;16) lub t(14;20), nadal istotnie obciaża rokowanie. Do innych niekorzystnych czynników prognostycznych zalicza się wystapienie podwójnej oporności na PI i IMiD oraz nawrót choroby po co najmniej trzech wcześniejszych liniach leczenia. Poprawa wyników leczenia w tych grupach chorych wymaga wprowadzenia do obecnych strategii terapeutycznych nowych leków, o odmiennych od dotychczasowych mechanizmach dziatania, co daje szanse na przetamanie rozwijajacej sie oporności. Wśród zarejestrowanych w ostatnich latach leków szczególna nadzieje pod tym wzgledem budza daratumumab i elotuzumab - przeciwciata monoklonalne (MoAb) skierowane przeciwko antygenom powierzchniowym komórek szpiczakowych. Wbadaniach klinicznych nad daratumumabem, pierwszym MoAb skierowanym przeciwko antygenowi CD38, wykazano jego wysoka skuteczność kliniczna $i$ korzystny profil bezpieczeństwa u pacjentów z opornym i/lub nawrotowym PCM, zarówno w monoterapii, jak i terapii skojarzonej z PI $i$ IMiD. W niniejszej pracy dokonano przegladu wyników badań klinicznych z zastosowaniem daratumumabu $w$ leczeniu PCM, ze szczególnym uwzględnieniem aktywności tego leku w grupie chorych obciażonych wysokim ryzykiem.
\end{abstract}

\section{Słowa kluczowe: szpiczak plazmocytowy, nawrót, oporność, daratumumab, przeciwciała monoklonalne}

Hematologia 2017; 8, 4: 255-264

\begin{abstract}
Despite the significant progress achieved during last two decades, plasma cell myeloma (PCM) remains an incurable disease. The greatest challenge in clinical practice is the optimal treatment of the high-risk group of patients. Numerous clinical trials demonstrated that presence of high-risk cytogenetic aberrations, such as del17p, t(4;14), t(14;16) lub t(14;20), still negatively affects patients' outcomes in the current era of modern anti-myeloma agents such as proteasome inhibitors (PI) or immunomodulatory drugs (IMiD). Among other groups of patients with unfavorable prognosis are
\end{abstract}

Adres do korespondencji: Aleksander Salomon-Perzyński, Klinika Hematologii, Instytut Hematologii i Transfuzjologii, ul. Indiry Gandhi 14, 02-776 Warszawa, tel./faks: 223496 334, 223496 335, e-mail: salomon.perzynski@gmail.com 
patients who are refractory to PIs and IMiD and patients with relapsed disease who had received three or more prior lines of therapy. Improving treatment outcomes in these patients requires novel drugs with different mechanisms of action, which would be able to overcome resistance to standard therapy. In this context, daratumumab i elotuzumab - two novel monoclonal antibodies (MoAbs) directed against myeloma cell surface antigens are of great interest. Daratumumab, a first-in-class anti-CD38 MoAb, has shown significant clinical activity and acceptable toxicity profile in relapsed/ /refractory PCM, in monotherapy as well as in combination with PI or IMiD. In this review, we discuss the role of daratumumab in the treatment of PCM, with emphasis on the efficacy of this drug in the group of high-risk patients.

Key words: plasma cell myeloma, relapse, refractoriness, daratumumab, monoclonal antibodies

Hematologia 2017; 8, 4: 255-264

\section{Wprowadzenie}

Szpiczak plazmocytowy (PCM, plasma cell myeloma) jest najczęstszym nowotworem wywodzącym się z komórek plazmatycznych, stanowiącym około $10 \%$ ogólu nowotworów hematologicznych [1]. Zapadalność roczna na PCM w Europie wynosi 5,3 przypadków/100 tys. osób [2]. W przeważającej większości sytuacji klinicznych PCM diagnozuje się u osób starszych, przy czym mediana wieku $\mathrm{w}$ momencie rozpoznania wynosi około 70 lat [3]. Szpiczak plazmocytowy pozostaje nowotworem nieuleczalnym, prowadzącym do blisko 25 tys. zgonów na terenie Europy w ciągu roku [2].

Istotny postęp, jaki się dokonał w terapii PCM w ostatnich kilkunastu latach, wyraża się wzrostem odsetków 5-letnich przeżyć z 34,5\% w roku 2000 do 49,6\% w roku 2013 [4]. Znaczącą poprawę rokowania osiągnięto wraz $z$ wprowadzeniem do leczenia nowych klas leków, takich jak inhibitory proteasomu (PI, proteasome inhibitors): bortezomib [5], karfilzomib [6], iksazomib [7] czy leki immunomodulujące (IMiD, immunomodulatory drugs): talidomid [8], lenalidomid [9], pomalidomid [10]. Na poprawę wyników leczenia w ostatnich 20 latach wpływało także ugruntowanie się roli konsolidacji leczenia pierwszej linii za pomocą wysokodawkowanej chemioterapii wspomaganej autologicznym przeszczepieniem krwiotwórczych komórek macierzystych w grupie młodszych pacjentów [11].

W dobie nowoczesnych leków przeciwszpiczakowych u znaczącej większości nowo zdiagnozowanych chorych na PCM uzyskuje się odpowiedź na leczenie, jednak odpowiedź ta pozostaje przejściowa, a rozwój oporności na terapię jest niemal na stałe wpisany w przebieg kliniczny choroby [12]. Coraz więcej danych wskazuje na to, że u podłoża rozwoju oporności na terapię leży ewolucyjna natura PCM wyrażająca się w procesie ciągłej konkurencji i selekcji zróżnicowanych genetycznie i fenotypowo populacji subklonalnych tworzących masę nowotworu [13, 14]. $Z$ powyższych względów uważa się, że osiągnięcie długotrwałej kontroli nad tak heterogenną klonalnie chorobą wymaga poszerzenia obecnie stosowanych strategii terapeutycznych o nowe leki, ukierunkowane na odmienne punkty uchwytu i wykazujące zróżnicowane mechanizmy działania, co może spowodować przełamanie nabywanej $\mathrm{w}$ trakcie standardowego leczenia oporności.

Należy podkreślić, że korzyści kliniczne związane $z$ wprowadzeniem nowoczesnych terapii nie dotyczą $\mathrm{w}$ równym stopniu wszystkich podtypów biologicznych PCM. Poprawa rokowania jest najsłabiej wyrażona w odniesieniu do grupy tak zwanych chorych wysokiego ryzyka. Mimo wprowadzenia do leczenia nowych leków przeciwszpiczakowych chorzy obciążeni aberracjami cytogenetycznymi wysokiego ryzyka (HRA, high-risk abnormalities), tj. del17p, $\mathrm{t}(4 ; 14), \mathrm{t}(14 ; 16)$ lub $\mathrm{t}(14 ; 20)$, osiągają znamiennie krótsze mediany przeżycia całkowitego (OS, overall survival) (odpowiednio 2,7 i 4,9 roku w przypadku występowania 2 i 1 HRA $v$. 8,3 roku w przypadku standardowego ryzyka cytogenetycznego) i przeżycia wolnego od progresji choroby (PFS, progression-free survival) (odpowiednio 1,2 i 1,5 roku w przypadku występowania 2 i 1 HRA v. 2,1 roku w przypadku standardowego ryzyka cytogenetycznego) [15].

Możliwość indukcji głębokiej i długotrwałej odpowiedzi jest również niezbędnym warunkiem poprawy wyników leczenia u chorych podwójnie opornych (DR-PCM, double-refractory plasma cell myeloma) na PI i IMiD oraz chorych, u których doszło do nawrotu choroby po co najmniej trzech wcześniejszych liniach leczenia obejmujących stosowanie PI i IMiD. Obie te grupy chorych cechują się bardzo niekorzystnym rokowaniem. 


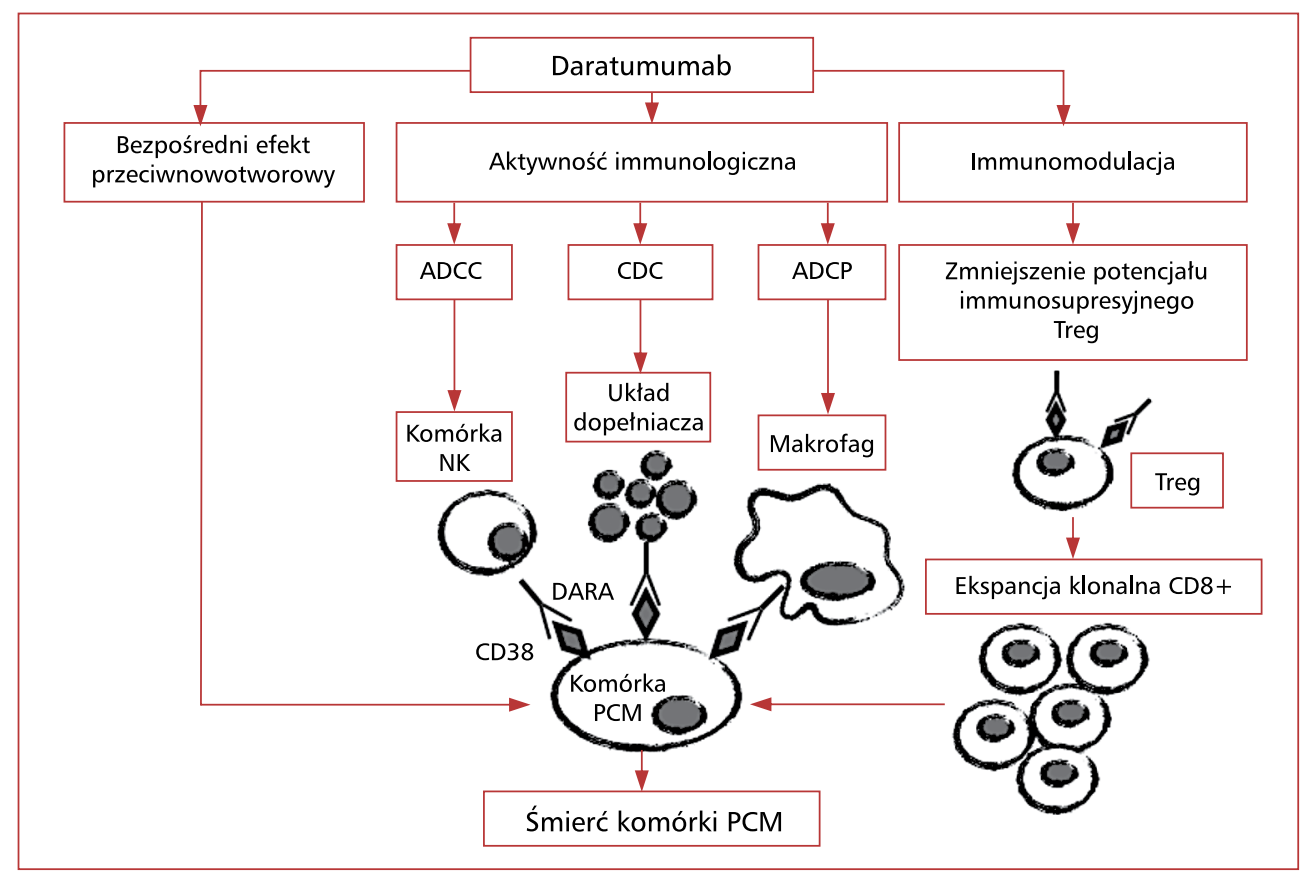

Rycina 1. Mechanizm działania daratumumabu (DARA); ADCC — cytotoksyczność komórkowa zależna od przeciwciał; CDC - cytotoksyczność zależna od układu dopełniacza; ADCP — fagocytoza zależna od przeciwciał; NK — komórka naturalnej cytotoksyczności; Treg — limfocyty T regulatorowe; PCM — szpiczak plazmocytowy

Figure 1. Daratumumab (DARA) mechanism of action; ADCC - antibody-dependent cellular cytotoxicity; CDC — complement-dependent cytotoxicity; ADCP — antibody-dependent cellular phagocytosis; NK — natural killer; Treg — regulatory T-cell; PCM — plasma cell myeloma

W świetle ostatnio opublikowanych wyników wieloośrodkowego badania retrospektywnego przeprowadzonego przez Międzynarodową Grupę Roboczą ds. Szpiczaka (IMWG, International Myeloma Working Group) mediana OS w grupie 543 pacjentów $z$ nawrotem choroby po co najmniej trzech liniach leczenia, opornych na PI (bortezomib lub karfilzomib) oraz IMiD (lenalidomid lub pomalidomid), wynosiła 13 miesięcy [16]. W innej analizie, w której oceniano wyniki leczenia grupy 662 pacjentów podwójnie opornych na PI i IMiD lub $z$ nawrotem choroby po co najmniej 3 liniach leczenia zawierających PI IMiD, mediana OS nie przekraczała 8 miesięcy [17].

Wśród ostatnio zarejestrowanych leków przeciwciała monoklonalne (MoAb, monoclonal antibodies) ukierunkowane na antygeny powierzchniowe komórek szpiczakowych wnoszą nową jakość do leczenia PCM. Daratumumab, pierwsze oceniane wbadaniach klinicznych MoAb skierowane przeciwko antygenowi CD38, wykazało znaczną skuteczność kliniczną i korzystny profil bezpieczeństwa zarówno w monoterapii [18-20], jak i w skojarzeniu $z$ deksametazonem oraz lenalidomidem [21] lub deksametazonem i bortezomibem [22], oraz uzy- skało niedawno pozytywne rekomendacje amerykańskiej Agencji ds. Żywności i Leków (FDA, Food and Drug Administration) i Europejskiej Agencji Leków (EMA, European Medicines Agency) do stosowania $\mathrm{w}$ grupie chorych $z$ opornym i/lub nawrotowym szpiczakiem plazmocytowym (RR-PCM, relapsed and/or refractory plasma cell myeloma).

W niniejszej pracy dokonano przeglądu badań służących ocenie skuteczności daratumumabu w leczeniu RR-PCM, ze szczególnym uwzględnieniem aktywności tego leku w grupie chorych wysokiego ryzyka.

\section{Mechanizm działania daratumumabu}

W badaniach przedklinicznych wykazano wiele odrębnych mechanizmów aktywności przeciwszpiczakowej daratumumabu (ryc. 1). W następstwie związania antygenu CD38 przez lek dochodzi do indukcji układu dopełniacza (CDC, complement-dependent cytotoxicity) i lizy komórki szpiczakowej wskutek formowania na jej powierzchni kompleksu atakującego błonę (MAC, membrane attack complex) [23]. Jednocześnie jest aktywowany proces cytotoksyczności zależnej od 
przeciwcial (ADCC, antibody-dependent cellular cytotoxicity), w którym komórki efektorowe, między innymi komórki naturalnej cytotoksyczności (NK, natural killer), indukują śmierć komórki nowotworowej na drodze wiązania $z$ fragmentem Fc przeciwciała [23]. Co ważne, aktywacja ADCC przez daratumumab odbywa się w obecności komórek podścieliska szpiku kostnego, co sugeruje, że lek ten znosi, przynajmniej częściowo, protekcyjny wpływ mikrośrodowiska nisz szpikowych na komórki PCM [23].

W odniesieniu do mechanizmów działania terapii opartych na skojarzeniu daratumumabu i IMiD szczególne znaczenie wydaje się mieć wzmacniający wpływ lenalidomidu na indukowaną przez daratumumab ADCC, wyrażający się przede wszystkim nasileniem aktywności cytotoksycznych komórek efektorowych [24, 25]. Podkreślenia wymaga fakt, $\dot{z}$ e synergizm ten jest obserwowany zarówno w odniesieniu do komórek szpiczakowych uzyskanych od pacjentów $z$ nowo rozpoznanym PCM [24], jak i od tych, u których rozwinęła się oporność na bortezomib i lenalidomid [24, 25].

Poza ADCC i CDC istotną rolę $\mathrm{w}$ aktywności przeciwszpiczakowej daratumumabu odgrywają immunofagocytoza, w której biorą udział głównie makrofagi [26], jak i zdolność do bezpośredniej indukcji apoptozy komórek PCM wskutek interakcji $\mathrm{MoAb} z$ receptorem dla $\mathrm{Fc}(\mathrm{Fc} \gamma \mathrm{R})$ [27]. Ponadto lek ten wywiera działanie immunomodulujące, między innymi poprzez wpływ na CD38-dodatnie regulatorowe komórki T, co skutkuje zmniejszeniem ich potencjału immunosupresyjnego, a w efekcie powoduje zwiększenie liczebności i nasilenie aktywności limfocytów T cytotoksycznych i pomocniczych [28].

Poziom ekspresji antygenu CD38 stanowi główną determinantę molekularną wrażliwości komórek szpiczakowych na daratumumab [29, 30]. U podłoża rozwoju oporności na daratumumab może więc leżeć selekcja i ekspansja CD38-negatywnych populacji subklonalnych i/lub adaptacja fenotypowa komórek nowotworowych, wyrażająca się utratą ekspresji antygenu CD38 (tzw. molecular bypass). Ostatnio opublikowano opis przypadku, w którym $\mathrm{w}$ czasie terapii daratumumabem obserwowano zmianę fenotypu choroby i pojawienie się CD38-negatywnych klonów odpowiedzialnych za progresję PCM [31], przy czym utratę ekspresji antygenu CD38 wiązano ze zmianami epigenetycznymi. Wstępne doniesienia wskazują, że pewien potencjał w przełamywaniu tego mechanizmu oporności może mieć kwas całkowicie transretinowy (ATRA, all-trans retinoic acid) będący induktorem ekspresji antygenu CD38 [29].

\section{Daratumumab w monoterapii w RR-PCM}

Skuteczność i bezpieczeństwo stosowania daratumumabu w monoterapii w leczeniu RR-PCM oceniono w badaniu II fazy MMY2002 SIRIUS [18]. Włączono do niego 106 pacjentów $z$ medianą liczby wcześniejszych linii leczenia wynoszącą pięć (zakres 2-14) [18]. Niemal całą grupę stanowili pacjenci z DR-PCM (95\%). Oporność na PI i IMiD nowej generacji, tj. karfilzomib i pomalidomid, obserwowano u odpowiednio 48\% i $63 \%$ pacjentów. Ublisko co trzeciego chorego stwierdzono tak zwaną poczwórną oporność, tj. oporność na bortezomib, karfilzomib, lenalidomid i pomalidomid. W grupie chorych otrzymujących daratumumab w dawce $16 \mathrm{mg} / \mathrm{kg} \mathrm{mc} .(\mathrm{n}=106)$ odsetek obiektywnych odpowiedzi (ORR, overall response rate), definiowany jako co najmniej odpowiedź częściowa (PR, partial response), wyniósł $29,2 \%$ i obejmował: 3 rygorystyczne odpowiedzi całkowite (sCR, stringent complete response), 10 bardzo dobrych odpowiedzi częściowych (VGPR, very good partial response) i 18 PR. Co ważne, odpowiedzi były osiągane niezależnie od liczby wcześniejszych linii leczenia, jak również występowania oporności na PI oraz IMiD. W grupie z DR-PCM odsetek ORR wyniósł 29,7\%. Podobny ORR $(28,6 \%)$ obserwowano w grupie chorych opornych na co najmniej trzy spośród czterech nowoczesnych leków przeciwszpiczakowych (bortezomib, karfilzomib, lenalidomid, pomalidomid). Mediany PFS i OS wynosity odpowiednio 3,7 i 17,5 miesiąca [18].

Łączna analiza wyników badania I/II fazy GEN501 i badania SIRIUS potwierdziła zdolność daratumumabu do indukowania głębokiej odpowiedzi u chorych $z$ RR-PCM poddanych uprzednio wielu liniom terapii [20]. W analizowanej populacji obejmującej 148 pacjentów, wśród których 86,5\% stanowili chorzy z DR-PCM, ORR wyniósł $31 \%$. Nie wykazano zależności między uzyskaniem odpowiedzi a liczbą wcześniejszych linii leczenia czy też faktem występowania oporności na PI oraz IMiD. Po medianie okresu obserwacji równej 20,7 miesiąca mediany czasu trwania odpowiedzi PFS i OS wynosity odpowiednio 7,6, 4 i 20,1 miesiąca [20].

Monoterapia daratumumabem cechowała się akceptowalnym profilem toksyczności. Wśród najczęściej występujących niehematologicznych działań niepożądanych obserwowano: kaszel, infekcje górnych dróg oddechowych, bóle pleców, nudności, zmęczenie. W zakresie toksyczności hematologicznej 3.-4. stopnia według CTCAE (Common Terminology Criteria for Adverse Events) dominowała niedokrwistość wikłająca przebieg leczenia 
u blisko co piątego pacjenta, $z$ kolei neutropenia i trombocytopenia występowały odpowiednio w $10 \%$ i $14 \%$ przypadków [20].

Skuteczność i tolerancję daratumumabu $\mathrm{u}$ chorych na RR-PCM leczonych w ramach codziennej praktyki klinicznej oceniono także w badaniu obserwacyjnym Polskiej Grupy Szpiczakowej (PLRG, Polish Lymphoma Research Group) $[32,33]$. Włączono do niego 30 pacjentów z RR-PCM, z medianą wcześniejszych linii leczenia wynoszącą cztery (zakres 2-10). Połowa chorych była podwójnie oporna na PI i IMiD. Odsetek RR wyniósł 41,4\%. W okresie obserwacji, którego mediana wynosiła 7,6 miesiąca, mediany OS i PFS nie zostały osiągnięte. Wstępne wyniki, w przeciwieństwie do wyników badania SIRIUS, sugerują mniejszą skuteczność daratumumabu w grupie pacjentów podwójnie opornych na PI i IMiD. Istotne, niehematologiczne działania niepożądane występowały u $30 \%$ pacjentów poddanych leczeniu daratumumabem i obejmowały: reakcje związane $z$ infuzją, zapalenie płuc, zakażenia górnych dróg oddechowych, zakażenia skóry i tkanek miękkich, zapalenie żuchwy, duszność.

Szczególnie interesująca jest wstępna obserwacja wskazująca na to, że leczenie daratumumabem może się wiązać $z$ uwrażliwieniem komórek szpiczakowych na kolejne linie terapii, włączając $\mathrm{w}$ to terapie lekami już uprzednio stosowanymi [20]. Jeśli znajdzie to potwierdzenie $\mathrm{w}$ dalszych badaniach, to ugruntuje kluczową pozycję daratumumabu w terapii RR-PCM. Konieczne jednak stanie się ustalenie, na którym etapie leczenia zastosowanie daratumumabu będzie się wiązać $z$ osiągnięciem największych korzyści klinicznych, tj. czy lepsze efekty terapeutyczne wyrażające się głębokością uzyskanej odpowiedzi, długością PFS i OS przyniesie strategia polegająca na podawaniu daratumumabu, PI oraz IMiD równocześnie w ramach złożonego schematu lekowego (tzw. strategia all-in-one), czy, co jest mniej prawdopodobne, strategia oparta na sekwencyjnym stosowaniu tych leków. Pytanie to wpisuje się w bardzo aktualny problem optymalnego leczenia zróżnicowanej klonalnie i ewoluującej w czasie choroby nowotworowej. Biorąc pod uwage fakt, że interwencja terapeutyczna stanowi jedną z najistotniejszych sił selekcji oddziaływujących na populacje subklonalne, a przetrwałe oporne subklony stanowią populację założycielską dla wznowy choroby, nie jest jasne, czy lepsze wyniki leczenia można uzyskać poprzez jednoczesne stosowanie leków ukierunkowanych na różne punkty uchwytu czy też korzystniej przedstawia się strategia stosowania tych leków w sposób sekwencyjny [34]. Nie można wykluczyć, że schematy wielolekowe mogą się przyczyniać do selekcji wysoce opornych subklonów, dając w efekcie szybką i głęboką odpowiedź wczesną, ale ostatecznie gorsze wyniki odległe. $Z$ kolei leczenie sekwencyjne, w którym siły selekcji są bardziej zrównoważone, a ich działanie jest rozłożone w czasie, może się cechować mniejszym potencjałem generowania oporności, a w efekcie osiągnięciem dłuższych PFS i OS, kosztem stosunkowo gorszych wyników wczesnych. Poznanie zasad ewolucji molekularnej PCM podczas leczenia onkohematologicznego wydaje się niezbędne do opracowania wysoce aktywnych, personalizowanych, wieloetapowych strategii terapeutycznych. Wymaga to jednak wprowadzenia małoinwazyjnych technik monitorowania zmian architektury subklonalnej choroby resztkowej.

\section{Terapie skojarzone}

Daratumumab wykazuje potencjał indukowania głębokiej odpowiedzi u znacznego odsetka chorych na RR-PCM leczonych wcześniej wieloma liniami chemioterapii, jednak fakt stosunkowo krótkiego czasu utrzymywania się odpowiedzi ogranicza korzyść kliniczną ze stosowania tego leku w monoterapii. Coraz więcej danych wskazuje na wysoką aktywność schematów skojarzonych zawierających daratumumab (tab. 1). Wyniki badań klinicznych, w których oceniano kombinacje trójelkowe kojarzące daratumumab $z$ deksametazonem i lenalidomidem lub $z$ deksametazonem i bortezomibem, wskazują, że triplety lekowe mają potencjał, aby się stać leczeniem $z$ wyboru u chorych na RR-PCM. Monoterapia daratumumabem może jednak stanowić optymalną opcję leczenia u chorych, którzy nie kwalifikują się do intensywnego leczenia skojarzonego, między innymi z powodu wspólistniejących obciążeń.

Skuteczność kliniczną terapii opartej na daratumumabie w skojarzeniu $z$ lenalidomidem i deksametazonem w leczeniu RR-PCMM oceniono $\mathrm{w}$ randomizowanym badaniu III fazy POLLUX [21]. Włączono do niego 569 pacjentów z progresją choroby po co najmniej jednej linii leczenia, spośród których 286 chorych włączono do grupy otrzymującej daratumumab w skojarzeniu $z$ lenalidomidem i deksametazonem, a 283 do grupy otrzymującej lenalidomid $z$ deksametazonem. Badana grupa osiągnęła istotnie wyższy ORR $(92,9 \%$ v. $76,4 \%)$, wyższy odsetek głębokich odpowiedzi (co najmniej całkowita remisja [CR]; 43,1\% v. 19,2\%) i częstszą negatywizację minimalnej choroby resztkowej (MRD, minimal residual disease) 
Tabela 1. Zestawienie badań klinicznych służących ocenie daratumumabu w leczeniu chorych na nawrotowego i/lub opornego szpiczaka plazmocytowego

Table 1. A summary of clinical trials evaluating daratumumab in the treatment of patients with relapsed/refractory plasma cell myeloma

\begin{tabular}{|l|c|c|c|c|c|}
\hline Badanie & Faza & Interwencja terapeutyczna & $\begin{array}{c}\text { Wcześniejsze linie leczenia } \\
\text { mediana (zakres) }\end{array}$ & $\begin{array}{c}\text { ORR } \\
\text { (\%) }\end{array}$ & $\begin{array}{c}\text { Mediana PFS } \\
\text { (miesiące) }\end{array}$ \\
\hline GEN501 & I-II & DARA w monoterapii & $4(3-10)$ & 36 & 5,6 \\
\hline SIRIUS & II & DARA w monoterapii & $5(2-14)$ & 29 & 3,7 \\
\hline NCT01998971* & Ib & DARA + Pom-Dex* & $4(1-13)$ & 60 & 8,8 \\
\hline POLLUX & III & DARA + Len-Dex v. Len-Dex & $1(1-11)$ & 93 & Nieosiągnięta \\
\hline CASTOR & III & DARA + Bort-Dex v. Bort-Dex & $2(1-10)$ & 82 & Nieosiągnięta \\
\hline
\end{tabular}

*W badaniu są oceniane liczne schematy skojarzone zawierające DARA; przedstawione dane dotyczą wyłącznie schematu daratumumab-pomalidomid-deksametazon; ORR (objective response rate) — odsetek obiektywnych odpowiedzi; PFS (progression-free survival) — przeżycie wolne od progresji; DARA — daratumumab; Pom - pomalidomid; Dex — deksametazon; Len - lenalidomid; Bort — bortezomib

$\left(22,4 \%\right.$ v. 4,6\%, poziom czułości $\left.10^{-5}\right)$. Co ważne, wraz z pogłębianiem się odpowiedzi obserwowano wydłużanie się PFS. Odsetek pacjentów wolnych od progresji choroby po 12 miesiącach wynosił $83,2 \%(95 \% 78,3-87,2)$ w grupie leczonej daratumumabem i $60,1 \%$ (95\% CI 54-65,7) w grupie kontrolnej. Dolączenie daratumumabu do lenalidomidu i deksametazonu wiązało się z 63-procentowym obniżeniem ryzyka progresji choroby lub zgonu (skorygowany współczynnik ryzyka [HR, hazard ratio] 0,37; 95-proc. przedział ufności [CI, confidence interval] 0,27-0,52). W okresie obserwacji, którego mediana wynosiła 13,5 miesiąca, mediana PFS w grupie przyjmującej daratumumab nie została osiągnięta, natomiast $\mathrm{w}$ grupie kontrolnej wyniosła 18,4 miesiąca. Przy zastrzeżeniu, że do badania POLLUX włączono stosunkowo niewielu pacjentów, którzy wcześniej zostali poddani co najmniej trzem liniom leczenia $(19,2 \%)$ lub byli oporni na PI (odpowiednio 19,9 i 16,3\% w grupach badanej i kontrolnej) albo podwójnie oporni na PI i IMiD (odpowiednio 2,4 i 4,9\% w grupach badanej i kontrolnej), analiza w podgrupach nie wykazała niekorzystnego wpływu ani liczby przebytych linii terapii przeciwszpiczakowej, ani oporności na PI na PFS w grupie przyjmującej daratumumab. Znacząca aktywność kliniczna tripletu lekowego nie wiązała się $z$ istotnym pogorszeniem profilu bezpieczeństwa terapii. Wśród dominujących działań niepożądanych 3. i 4. stopnia według CTCAE w badanej grupie częściej obserwowano neutropenię $(51,9 \%$ v. 37\%). Reakcje wikłające przebieg infuzji daratumumabu obserwowano w $47,7 \%$ przypadków, w większości o łagodnym charakterze (1. lub 2. stopień wg CTCAE) i ograniczające się do podania pierwszej dawki leku [21].

Ostatnio opublikowano wyniki badania, w którym oceniano bezpieczeństwo i skuteczność kliniczną schematu trójlekowego złożonego $z$ dara- tumumabu, IMiD nowej generacji — pomalidomidu oraz deksametazonu w leczeniu chorych $z$ progresją PCM po co najmniej dwóch wcześniejszych liniach terapii [35]. W przeciwieństwie do badania POLLUX istotny odsetek chorych włączonych do opisywanego badania stanowili pacjenci poddani wcześniej co najmniej 3 liniom leczenia przeciwszpiczakowego (76\%). Obiektywną odpowiedź uzyskano u $60 \%$ pacjentów, w tym u $58 \%$ chorych na DR-PCM. U 29\% pacjentów, którzy uzyskali co najmniej CR, terapia trójlekowa wiązała się $z$ negatywizacją MRD (na poziomie czułości 10-5). Przy medianie okresu obserwacji wynoszącej 13,1 miesiąca mediany PFS i OS wynosity odpowiednio 8,8 i 17,5 miesiąca, $z$ kolei mediana czasu trwania odpowiedzi nie została osiągnięta. Terapia trójlekowa pozwalała zatem na uzyskanie głębokiej i długotrwałej odpowiedzi $\mathrm{w}$ grupie intensywnie przeleczonych chorych na RR-PCM, przy zachowaniu korzystnego profilu bezpieczeństwa. $Z$ wyjątkiem reakcji związanych $z$ infuzją, jak również częstszego występowania neutropenii niepowikłanej zakażeniem dołączenie daratumumabu do pomalidomidu i deksametazonu nie wiązało się $z$ istotnym nasileniem działań niepożądanych terapii [35].

Przewagę schematu trójlekowego, zawierającego daratumumab, bortezomib i deksametazon, nad bortezomibem $z$ deksametazonem w leczeniu pacjentów $z$ RR-PCM $z$ progresją choroby po co najmniej jednej linii terapii wykazano w randomizowanym badaniu III fazy CASTOR [22]. Włączono do niego 498 pacjentów, wśród których 23,9\% stanowili chorzy poddani wcześniej co najmniej trzem liniom leczenia, a 32,9\% - pacjenci oporni na IMiD. Podobnie do badania POLLUX w grupie leczonej daratumumabem znamiennie częściej obserwowano odpowiedzi obiektywne (ORR 82,9\% $v .63,2 \%)$, w tym odpowiedzi głębokie, tj. co najmniej VGPR $(59,2 \%$ v. $29,1 \%)$ i co najmniej CR $(19,2 \%$ 
v. 9,0\%). Odsetek pacjentów wolnych od progresji choroby po 12 miesiącach wynosił $60,7 \%$ w grupie badanej i 26,9\% w grupie kontrolnej. Dołączenie daratumumabu do bortezomibu i deksametazonu wiązało się z 61-procentową redukcją ryzyka progresji choroby lub zgonu (HR 0,39; 95\% CI 0,28-0,53). $\mathrm{W}$ okresie obserwacji, którego mediana wynosiła 7,4 miesiąca, mediana PFS nie została osiągnięta $\mathrm{w}$ grupie leczonej daratumumabem, natomiast w grupie kontrolnej wyniosła 7,2 miesiąca. Leczenie według schematu trójlekowego wiązało się z częstszym występowaniem neutropenii i trombocytopenii 3. i 4. stopnia według CTCAE (odpowiednio $12,8 \%$ v. $4,2 \%$ i $45,3 \%$ v. 32,9\%). Reakcje związane $z$ infuzją daratumumabu, obserwowane u $45,3 \%$ pacjentów, w większości przypadków cechowały się niewielkim nasileniem (1. lub 2. stopień wg CTCAE w $91,4 \%$ przypadków), a ich występowanie niemal u wszystkich chorych obserwowano przy podaniu pierwszej dawki leku [22].

W świetle wyników dwóch analiz zaprezentowanych podczas zeszłorocznej konferencji ASH (American Society of Hematology) terapia oparta na schematach trójlekowych zawierających daratumumab wiąże się $z$ istotnym klinicznie wydłużeniem mediany PFS u chorych opornych na bortezomib lub lenalidomid. Przy medianie okresu obserwacji wynoszącej 13,5 miesiąca $\mathrm{w}$ podgrupie chorych opornych na bortezomib leczonych według schematu daratumumab-lenalidomid-deksametazon mediana PFS nie została osiągnięta, $z$ kolei u chorych leczonych zgodnie ze schematem lenalidomid-deksametazon wyniosła 10,3 miesięcy [36]. Terapia według schematu daratumumab-lenalidomid-deksametazon wiązała się z 2-krotnie częstszym uzyskiwaniem przez pacjentów głębokich odpowiedzi (co najmniej VGPR 75\% v. 36\%). Podobnie wśród chorych opornych na ostatnią linię leczenia, w której stosowano lenalidomid, schemat daratumumab-bortezomib-deksametazon pozwalał na uzyskanie znamiennie dłuższego PFS $\mathrm{i}$ istotnie wyższego ORR niz schemat bortezomib-deksametazon (mediana PFS odpowiednio 10,3 v. 4,4 miesiąca, ORR odpowiednio $81 \% v .50 \%$ ). W grupie chorych leczonych daratumumabem około 4-krotnie wyższy był również odsetek uzyskanych odpowiedzi wysokiej jakości (co najmniej VGPR 54\% v. 12\%, co najmniej CR $20 \%$ v. 5\%) [37].

Wobec szczególnie trudnego problemu klinicznego, który stanowi dobór optymalnego postępowania u pacjentów z RR-PCM wysokiego ryzyka cytogenetycznego, wyjątkowo zachęcająco przedstawiają się wyniki pogłębionej analizy da- nych $\mathrm{z}$ badań POLLUX i CASTOR zaprezentowane podczas tegorocznej konferencji ASCO (Amercian Society of Clinical Oncology). Wskazują one bowiem, że korzyści kliniczne ze stosowania schematów trójlekowych zawierających daratumumab są osiągane niezależnie od profilu cytogenetycznego choroby. Znamiennie dłuższą medianę PFS w grupach leczonych daratumumabem obserwowano zarówno $\mathrm{w}$ grupie chorych cechujących się standardowym ryzykiem cytogenetycznym, jak i wśród pacjentów obarczonych co najmniej jedną niekorzystną rokowniczo HRA, tj. del17p, $\mathrm{t}(4 ; 14)$ lub $\mathrm{t}(14,16)$. W grupie chorych $z$ HRA leczonych zgodnie ze schematem daratumumab-lenalidomid-deksametazon, przy medianie okresu obserwacji wynoszącej 17,3 miesiąca, mediany PFS nie osiągnięto, $z$ kolei $\mathrm{u}$ chorych leczonych według schematu daratumumab-bortezomib-deksametazon wyniosła 11,2 miesiąca (mediana okresu obserwacji 13 miesięcy) [38]. Dane te są obiecujące, niemniej jednak istotnie krótszy czas obserwacji nie pozwala ocenić, czy schematy trójlekowe zawierające daratumumab stanowią optymalną alternatywę dla schematu karfilzomib-lenalidomid-deksametazon, który wykazał niedawno znaczącą aktywność kliniczną w leczeniu chorych na RR-PCM wysokiego ryzyka cytogenetycznego, wyrażającą się medianą PFS wynoszącą 23,1 miesiąca [39].

W kontekście przytoczonych danych szczególnie interesująco wygląda perspektywa skojarzenia karfilzomibu i daratumumabu w leczeniu chorych na RR-PCM o niekorzystnym rokowniczo profilu cytogenetycznym. Schemat ten jest oceniany $\mathrm{w}$ randomizowanym badaniu III fazy CANDOR (NCT03158688).

\section{Miejsce daratumumabu \\ w aktualnej strategii terapeutycznej dla chorych na PCM}

Wyniki ostatnio opublikowanego badania, w którym porównywano grupę chorych leczonych daratumumabem $\mathrm{w}$ monoterapii $\mathrm{w}$ ramach badań GEN501 i SIRIUS $z$ historyczną grupą kontrolną obejmującej pacjentów $z$ DR-PCM lub z progresją choroby po podaniu uprzednio co najmniej trzech linii leczenia, wskazują na przewagę daratumumabu $\mathrm{w}$ monoterapii nad innymi strategiami terapeutycznymi stosowanymi u chorych na RR-PCM w codziennej praktyce klinicznej [40]. Współczynnik ryzyka dla OS w grupie chorych leczonych daratumumabem względem historycznej grupy kontrolnej wynosił 0,33 (95\% CI, 0,24-0,46), co odzwierciedla 67-procentowe obniżenie 
prawdopodobieństwa zgonu w grupie chorych leczonych daratumumabem. Na podkreślenie zasługuje fakt, że w grupie chorych otrzymujących daratumumab status podwójnej oporności na PI oraz IMiD nie wykazywał niekorzystnego wpływu na OS. Co więcej, chorych potrójnie i poczwórne opornych leczonych daratumumabem cechowało znamiennie dłuższe OS niż chorymi z grupy kontrolnej, którzy zachowywali wrażliwość na PI i IMiD [40].

Aktywność kliniczna daratumumabu w monoterapii, wyrażająca się zdolnością do indukcji obiektywnej odpowiedzi u około $30 \%$ pacjentów $z$ RR-PCM poddanych wcześniej wielu liniom leczenia, $u$ których doszło do rozwoju wielolekowej oporności, przedstawia się korzystnie w porównaniu $z$ innymi nowoczesnymi lekami przeciwszpiczakowymi stosowanymi w monoterapii w chorobie progresywnej. Skuteczność karfilzomibu w monoterapii u chorych $z$ progresją PCM po co najmniej trzech wcześniejszych liniach leczenia oceniano w randomizowanym badaniu III fazy FOCUS [41]. W grupie pacjentów otrzymujących karfilzomib, wśród których $62 \%$ stanowili chorzy podwójnie oporni na PI oraz IMiD, ORR wyniósł $19,1 \%$. Nie stwierdzono istotnych różnic w zakresie mediany OS między grupą otrzymującą karfilzomib w monoterapii a grupą kontrolną którą stanowili pacjenci leczeni małymi dawkami glikokortykosteroidów, opcjonalnie uzupełnionymi cyklofosfamidem (mediany OS odpowiednio 10,2 i 10 miesięcy). W randomizowanym badaniu II fazy, w którym porównywano pomalidomid w monoterapii $\mathrm{z}$ pomalidomidem stosowanym $\mathrm{w}$ skojarzeniu $z$ małymi dawkami deksametazonu u chorych poddanych wcześniej co najmniej dwóm liniom terapii, w grupie chorych podwójnie opornych na PI oraz IMiD monoterapia pomalidomidem wiązała się $z$ uzyskaniem co najmniej PR u co 5. pacjenta (ORR 21\%) [42]. Mediany PFS i OS wynosily odpowiednio 2 i 12,5 miesiąca i nie różniły się istotnie względem grupy leczonej pomalidomidem w skojarzeniu $z$ deksametazonem. $Z$ kolei monoterapia lenalidomidem w grupie 222 chorych na RR-PCM wiązała się uzyskaniem obiektywnej odpowiedzi u $26 \%$ pacjentów. Mediany PFS i OS wynosily odpowiednio 4,9 i 23,2 miesiąca [43]. Należy jednak zauważyć, że w badanej populacji co najmniej trzy linie wcześniejszej terapii otrzymało tylko $67 \%$ chorych, stosunkowo niewielki odsetek pacjentów (43\%) otrzymywał również bortezomib w ramach wcześniejszych strategii terapeutycznych.

Wprowadzenie daratumumabu stanowi przełom w leczeniu PCM. Lek ten wykazuje znamienną efektywność kliniczną w monoterapii, pozwalając w szczególności na poprawę wyników leczenia $\mathrm{u}$ istotnego odsetka niekorzystnie rokujących chorych, u których rozwinęła się podwójna oporność na PI oraz IMiD, a także u chorych na PCM cechujących się wysokim ryzykiem cytogenetycznym. W świetle niedawno zaktualizowanych wytycznych ESMO (European Society for Medical Oncology) monoterapię daratumumabem należy rozważyć u chorych $z$ drugim i kolejnym nawrotem choroby [1]. W aktualnych zaleceniach NCCN (National Comprehensive Cancer Network) monoterapia daratumumabem jest wskazana u pacjentów $z$ nawrotem PCM po co najmniej trzech wcześniejszych liniach leczenia zawierających PI i IMiD lub u chorych podwójnie opornych na PI i IMiD (kategoria 2A zaleceń) [44].

Terapie trójlekowe obejmujące skojarzenia daratumumabu $z$ deksametazonem i lenalidomidem [21], bortezomibem [22] lub pomalidomidem [35] wykazują znaczącą aktywność przeciwszpiczakową, mając przy tym akceptowalny profil bezpieczeństwa, co sprawia, że obecnie charakteryzują się potencjałem, aby stać się leczeniem $z$ wyboru w grupie chorych na RR-PCM. W wytycznych NCCN triplety daratumumab-bortezomib-deksametazon i daratumumab-lenalidomid-deksametazon wymienia się wśród schematów preferowanych w leczeniu choroby nawrotowej (kategoria 1 zaleceń) [44]. Podobnie w zaleceniach ESMO zastosowanie tripletów daratumumab-bortezomib-deksametazon i daratumumab-lenalidomid-deksametazon należy rozważyć już w pierwszym nawrocie PCM [1].

Duże nadzieje wiąże się $z$ możliwością wykorzystania potencjału daratumumabu na wcześniejszych etapach leczenia PCM. Ocenie w ramach badań klinicznych w pierwszej linii leczenia PCM podlegają obecnie schematy skojarzone zawierające daratumumab oraz (a) bortezomib, talidomid, deksametazon (NCT02541383, faza 3); (b) bortezomib, lenalidomid, deksametazon (NCT02874742, faza 2); (c) karfilzomib, lenalidomid, deksametazon (NCT03290950, faza 2); (d) iksazomib, lenalidomid, deksametazon (NCT03012880, faza II); (e) lenalidomid i deksametazon (NCT02252172, faza 3); (f) bortezomib, melfalan, prednizon (NCT02195479, faza III) oraz (g) cyklofosfamid, bortezomib, deksametazon (NCT02951819, faza II).

\section{Piśmiennictwo}

1. Moreau P, San Miguel J, Sonneveld P, et al. ESMO Guidelines Committee. Multiple myeloma: ESMO Clinical Practice Guidelines for diagnosis, treatment and follow-up. Ann Oncol. 2017; 28(Suppl 4): iv52-iv61, doi: 10.1093/annonc/mdx096, indexed in Pubmed: 28453614. 
2. Ferlay J, Soerjomataram I, Ervik M, et al. GLOBOCAN 2012 v1.0, Cancer incidence and mortality worldwide: IARC CancerBase No. 11 [Internet]. International Agency for Research on Cancer, Lyon 2013. http://globocan.iarc.fr (accessed on 29/09/2017).

3. Palumbo A, Bringhen S, Ludwig H, et al. Personalized therapy in multiple myeloma according to patient age and vulnerability: a report of the European Myeloma Network (EMN). Blood. 2011; 118(17): 4519-4529, doi: 10.1182/blood-2011-06-358812, indexed in Pubmed: 21841166.

4. Howlader, N., et al. http://globocan.iarc.fr (accessed on 29/09/2017).

5. Mateos MV, Richardson PG, Schlag R, et al. Bortezomib plus melphalan and prednisone compared with melphalan and prednisone in previously untreated multiple myeloma: updated follow-up and impact of subsequent therapy in the phase III VISTA trial. J Clin Oncol. 2010; 28(13): 2259-2266, doi: 10.1200/JCO.2009.26.0638, indexed in Pubmed: 20368561.

6. Dimopoulos M, Moreau P, Palumbo A, et al. Carfilzomib and dexamethasone versus bortezomib and dexamethasone for patients with relapsed or refractory multiple myeloma (ENDEAVOR): a randomised, phase 3, open-label, multicentre study. Lancet Oncol. 2016; 17(1): 27-38, doi: 10.1016/s1470-2045(15)00464-7, indexed in Pubmed: 26671818.

7. Moreau P, Masszi T, Grzasko N, et al. TOURMALINE-MM1 Study Group. Oral ixazomib, lenalidomide, and dexamethasone for multiple myeloma. N Engl J Med. 2016; 374(17): 1621-1634, doi: 10.1056/NEJMoa1516282, indexed in Pubmed: 27119237.

8. Fayers PM, Palumbo A, Hulin C, et al. Nordic Myeloma Study Group, Italian Multiple Myeloma Network, Turkish Myeloma Study Group, Hemato-Oncologie voor Volwassenen Nederland, Intergroupe Francophone du Myélome, European Myeloma Network. Thalidomide for previously untreated elderly patients with multiple myeloma: meta-analysis of 1685 individual patient data from 6 randomized clinical trials. Blood. 2011; 118(5): 1239-1247, doi: 10.1182/blood-2011-03-341669, indexed in Pubmed: 21670471.

9. Dimopoulos M, Spencer A, Attal M, et al. Multiple Myeloma (010) Study Investigators. Lenalidomide plus dexamethasone for relapsed or refractory multiple myeloma. N Engl J Med. 2009; 361(5): 2123-2132, doi: 10.1056/NEJMoa070594, indexed in Pubmed: 18032762.

10. San Miguel J, Weisel K, Moreau P, et al. Pomalidomide plus low-dose dexamethasone versus high-dose dexamethasone alone for patients with relapsed and refractory multiple myeloma (MM-003): a randomised, open-label, phase 3 trial. Lancet Oncol. 2013; 14(11): 1055-1066, doi: 10.1016/S1470-2045(13)70380-2, indexed in Pubmed: 24007748 .

11. Attal M, Harousseau JL, Stoppa AM, et al. A prospective, randomized trial of autologous bone marrow transplantation and chemotherapy in multiple myeloma. Intergroupe Français du Myélome. N Engl J Med. 1996; 335(2): 91-97, doi: 10.1056/ /NEJM199607113350204, indexed in Pubmed: 8649495.

12. Sonneveld P, De Wit E, Moreau P. How have evolutions in strategies for the treatment of relapsed/refractory multiple myeloma translated into improved outcomes for patients? Crit Rev Oncol Hematol. 2017; 112: 153-170, doi: 10.1016/j.critrevonc.2017.02.007, indexed in Pubmed: 28325256.

13. Lohr JG, Stojanov P, Carter SL, et al. Multiple Myeloma Research Consortium. Widespread genetic heterogeneity in multiple myeloma: implications for targeted therapy. Cancer Cell. 2014; 25(1): 91-101, doi: 10.1016/j.ccr.2013.12.015, indexed in Pubmed: 24434212.
14. Chesi M, Robbiani DF, Sebag M, et al. AID-dependent activation of a MYC transgene induces multiple myeloma in a conditional mouse model of post-germinal center malignancies. Cancer Cell. 2008; 13(2): 167-180, doi: 10.1016/j.ccr.2008.01.007, indexed in Pubmed: 18242516.

15. Binder M, Rajkumar SV, Ketterling RP, et al. Prognostic implications of abnormalities of chromosome 13 and the presence of multiple cytogenetic high-risk abnormalities in newly diagnosed multiple myeloma. Blood Cancer J. 2017; 7(9): e600, doi: 10.1038/ /bcj.2017.83, indexed in Pubmed: 28862698.

16. Kumar SK, Dimopoulos MA, Kastritis E, et al. Natural history of relapsed myeloma, refractory to immunomodulatory drugs and proteasome inhibitors: a multicenter IMWG study. Leukemia. 2017; 31(11): 2443-2448, doi: 10.1038/leu.2017.138, indexed in Pubmed: 28620163.

17. Usmani S, Ahmadi T, Ng Y, et al. Analysis of real-world data on overall survival in multiple myeloma patients with $\geq 3$ prior lines of therapy including a proteasome inhibitor (PI) and an immunomodulatory drug (IMiD), or double refractory to a PI and an IMiD. Oncologist. 2016 [Epub ahead of print], doi: 10.1634/ /theoncologist.2016-0104, indexed in Pubmed: 27486203.

18. Lonial S, Weiss B, Usmani S, et al. Daratumumab monotherapy in patients with treatment-refractory multiple myeloma (SIRIUS): an open-label, randomised, phase 2 trial. Lancet. 2016; 387(10027): 1551-1560, doi: 10.1016/s0140-6736(15)01120-4, indexed in Pubmed: 26778538.

19. Lokhorst HM, Plesner T, Laubach JP, et al. Targeting CD38 with daratumumab monotherapy in multiple myeloma. $\mathrm{N}$ Engl J Med. 2015; 373(13): 1207-1219, doi: 10.1056/NEJMoa1506348, indexed in Pubmed: 26308596.

20. Usmani SZ, Weiss BM, Plesner T, et al. Clinical efficacy of daratumumab monotherapy in patients with heavily pretreated relapsed or refractory multiple myeloma. Blood. 2016; 128(1): 37-44, doi: 10.1182/blood-2016-03-705210, indexed in Pubmed: 27216216.

21. Dimopoulos MA, Oriol A, Nahi H, et al. POLLUX Investigators. Daratumumab, lenalidomide, and dexamethasone for multiple myeloma. N Engl J Med. 2016; 375(14): 1319-1331, doi: 10.1056/ /NEJMoa1607751, indexed in Pubmed: 27705267.

22. Palumbo A, Chanan-Khan A, Weisel K, et al. CASTOR Investigators. Daratumumab, bortezomib, and dexamethasone for multiple myeloma. N Engl J Med. 2016; 375(8): 754-766, doi: 10.1056/ /NEJMoa1606038, indexed in Pubmed: 27557302.

23. Weers Mde, Tai YT, Veer MSv, et al. Daratumumab, a novel therapeutic human CD38 monoclonal antibody, induces killing of multiple myeloma and other hematological tumors. J Immunol. 2011; 186(3): 1840-1848, doi: 10.4049/jimmunol.1003032, indexed in Pubmed: 21187443.

24. van der Veer MS, de Weers M, van Kessel B, et al. Towards effective immunotherapy of myeloma: enhanced elimination of myeloma cells by combination of lenalidomide with the human CD38 monoclonal antibody daratumumab. Haematologica. 2011; 96(2): 284-290, doi: 10.3324/haematol.2010.030759, indexed in Pubmed: 21109694.

25. Nijhof IS, Groen RWJ, Noort WA, et al. Preclinical evidence for the therapeutic potential of CD38-targeted immuno-chemotherapy in multiple myeloma patients refractory to lenalidomide and bortezomib. Clin Cancer Res. 2015; 21(12): 2802-2810, doi: 10.1158/10780432.CCR-14-1813, indexed in Pubmed: 25398450.

26. Overdijk MB, Verploegen S, Bögels M, et al. Antibody-mediated phagocytosis contributes to the anti-tumor activity of the therapeutic 
antibody daratumumab in lymphoma and multiple myeloma. MAbs. 2015; 7(2): 311-321, doi: 10.1080/19420862.2015.1007813, indexed in Pubmed: 25760767.

27. Overdijk M, Jansen J, Nederend M, et al. The therapeutic CD38 monoclonal antibody daratumumab induces programmed cell death via Fc $\gamma$ receptor-mediated cross-linking. J Immunol. 2016; 197(3): 807-813, doi: 10.4049/jimmunol.1501351, indexed in Pubmed: 27316683 .

28. Krejcik J, Casneuf T, Nijhof IS, et al. Daratumumab depletes CD38+ immune regulatory cells, promotes T-cell expansion, and skews T-cell repertoire in multiple myeloma. Blood. 2016; 128(3): 384-394, doi: 10.1182/blood-2015-12-687749, indexed in Pubmed: 27222480.

29. Nijhof IS, Groen RWJ, Lokhorst HM, et al. Upregulation of CD38 expression on multiple myeloma cells by all-trans retinoic acid improves the efficacy of daratumumab. Leukemia. 2015; 29(10): 2039-2049, doi: 10.1038/leu.2015.123, indexed in Pubmed: 25975191.

30. Nijhof IS, Casneuf T, van Velzen J, et al. CD38 expression and complement inhibitors affect response and resistance to daratumumab therapy in myeloma. Blood. 2016; 128(7): 959-970, doi: 10.1182/ /blood-2016-03-703439, indexed in Pubmed: 27307294.

31. Minarik J, Novak M, Flodr P, et al. CD38-negative relapse in multiple myeloma after daratumumab-based chemotherapy. Eur J Haematol. 2017; 99(2): 186-189, doi: 10.1111/ejh.12902, indexed in Pubmed: 28470777.

32. Salomon-Perzyński A, Walter-Croneck A, Usnarska-Zubkiewicz $\mathrm{L}$, et al. Real-world results of daratumumab monotherapy in heavily pretreated relapsed/refractory multiple myeloma in Poland: a prospective observational study of the Polish Myeloma Group. Haematologica. 2017; 102(s2): 517-517.

33. Salomon-Perzyński A, Walter-Croneck A, Usnarska-Zubkiewicz L, et al. Daratumumab w monoterapii w leczeniu chorych $z$ opornym lub nawrotowym szpiczakiem plazmocytowym w codziennej praktyce klinicznej - badanie obserwacyjne Polskiej Grupy Szpiczakowej (PGSz). Acta Haematol Pol. 2017; 48(Suppl 1): 82-82.

34. Brioli A, Melchor L, Cavo M, et al. The impact of intra-clonal heterogeneity on the treatment of multiple myeloma. Br J Haematol. 2014; 165(4): 441-454, doi: 10.1111/bjh.12805, indexed in Pubmed: 24580032.

35. Chari A, Suvannasankha A, Fay JW, et al. Daratumumab plus pomalidomide and dexamethasone in relapsed and/or refractory multiple myeloma. Blood. 2017; 130(8): 974-981, doi: 10.1182/ /blood-2017-05-785246, indexed in Pubmed: 28637662.
36. Moreau P, Kaufman JL, Sutherland HJ, et al. Efficacy of daratumumab, lenalidomide and dexamethasone versus lenalidomide and dexamethasone alone for relapsed or refractory multiple myeloma among patients with 1 to 3 prior lines of therapy based on previous treatment exposure: updated analysis of pollux. Blood, 128(22), 489. http://www.bloodjournal.org/content/128/22/489 (Accessed August 26, 2017).

37. Chanan-Khan AA, Lentzsch S, Quach H, et al. Daratumumab, bortezomib and dexamethasone versus bortezomib and dexamethasone alone for relapsed or refractory multiple myeloma based on prior treatment exposure: updated efficacy analysis of castor. Blood, 128(22), 3313. http://www.bloodjournal.org/content/128/22/3313 (Accessed August 26, 2017).

38. Weisel K, San Mi, Cook G, et al. Efficacy of daratumumab in combination with lenalidomide plus dexamethasone (DRd) or bortezomib plus dexamethasone (DVd) in relapsed or refractory multiple myeloma (RRMM) based on cytogenetic risk status. J Clin Oncol. 2017; 35(15 Suppl): 8006.

39. Avet-Loiseau H, Fonseca R, Siegel D, et al. Carfilzomib significantly improves the progression-free survival of high-risk patients in multiple myeloma. Blood. 2016; 128(9): 1174-1180, doi: 10.1182/ /blood-2016-03-707596, indexed in Pubmed: 27439911.

40. Usmani SZ, Diels J, Ito T, et al. Daratumumab monotherapy compared with historical control data in heavily pretreated and highly refractory patients with multiple myeloma: an adjusted treatment comparison. Am J Hematol. 2017; 92(8): E146-E152, doi: 10.1002/ajh.24781, indexed in Pubmed: 28474745.

41. Hájek R, Masszi T, Petrucci MT, et al. A randomized phase III study of carfilzomib vs low-dose corticosteroids with optional cyclophosphamide in relapsed and refractory multiple myeloma (FOCUS). Leukemia. 2017; 31(1): 107-114, doi: 10.1038/ /leu.2016.176, indexed in Pubmed: 27416912.

42. Richardson PG, Siegel DS, Vij R, et al. Pomalidomide alone or in combination with low-dose dexamethasone in relapsed and refractory multiple myeloma: a randomized phase 2 study. Blood. 2014; 123(12): 1826-1832, doi: 10.1182/blood-2013-11-538835, indexed in Pubmed: 24421329.

43. Richardson P, Jagannath S, Hussein M, et al. Safety and efficacy of single-agent lenalidomide in patients with relapsed and refractory multiple myeloma. Blood. 2009; 114(4): 772-778, doi: 10.1182/ /blood-2008-12-196238, indexed in Pubmed: 19471019.

44. Kumar SK, Callander NS, Alsina M, et al. Multiple myeloma, version 3.2017, NCCN clinical practice guidelines in oncology. J Natl Compr Canc Netw. 2017; 15(2): 230-269, doi: 10.6004/ /jnccn.2017.0023, indexed in Pubmed: 28188192. 